SCIREA Journal of Clinical Medicine

ISSN: 2706-8870

http://www.scirea.org/journal/CM

April 4, 2021

SCIREA

Volume 6, Issue 3, June 2021

\title{
ATRIAL FIBRILLATION RELATED TO HEART ACCESSORY TISSUES IN A 36-YEAR-OLD WOMAN
}

\section{MAKANI BASSAKOUAHOU Jospin Karel}

Medical doctor, department of cardiology, teaching hospital of Brazzaville, Brazzaville, Congo

\section{MAYALA MAOGNAN Reine France}

Medical doctor, department of cardiology, teaching hospital of Brazzaville, Brazzaville, Congo

\section{IKAMA Méo Stéphane}

Medical doctor, department of cardiology, teaching hospital of Brazzaville, professor at the health science faculty, Marien Ngouabi university, Brazzaville, Congo

\section{KOUALA LANDA Chistian Michel}

Medical doctor, department of cardiology, teaching hospital of Brazzaville, Brazzaville, Congo

\section{KIMBALLY KAKY Gisèle}

Medical doctor, department of cardiology, teaching hospital of Brazzaville, professor at the health science faculty, Marien Ngouabi university, Brazzaville, Congo

Corresponding author :

MAKANI BASSAKOUAHOU Jospin Karel

Email : jospinmakani@gmail.com 


\begin{abstract}
We report a case of atrial fibrillation associated with cardiac accessory tissues in a 36-yearold patient. The clinical symptomatology was dominated by recurrent palpitations and right heart failure. Doppler echocardiography revealed a couple of cardiac accessory tissues causing dilatation of right cardiac chambers.
\end{abstract}

Keywords: Atrial fibrillation, heart failure, cardiac accessory tissue

\title{
Introduction
}

Cardiac accessory tissue is the presence of supernumerary structure in the heart. It can be made of muscle or membrane [1,2]. Rythm disorder is not common in that context apart of evoluated stage of tri-atrial heart [3]. The particularity of this case is the unusual number of accessory tissues and principally the occurrence of atrial fibrillation.

\section{Case report}

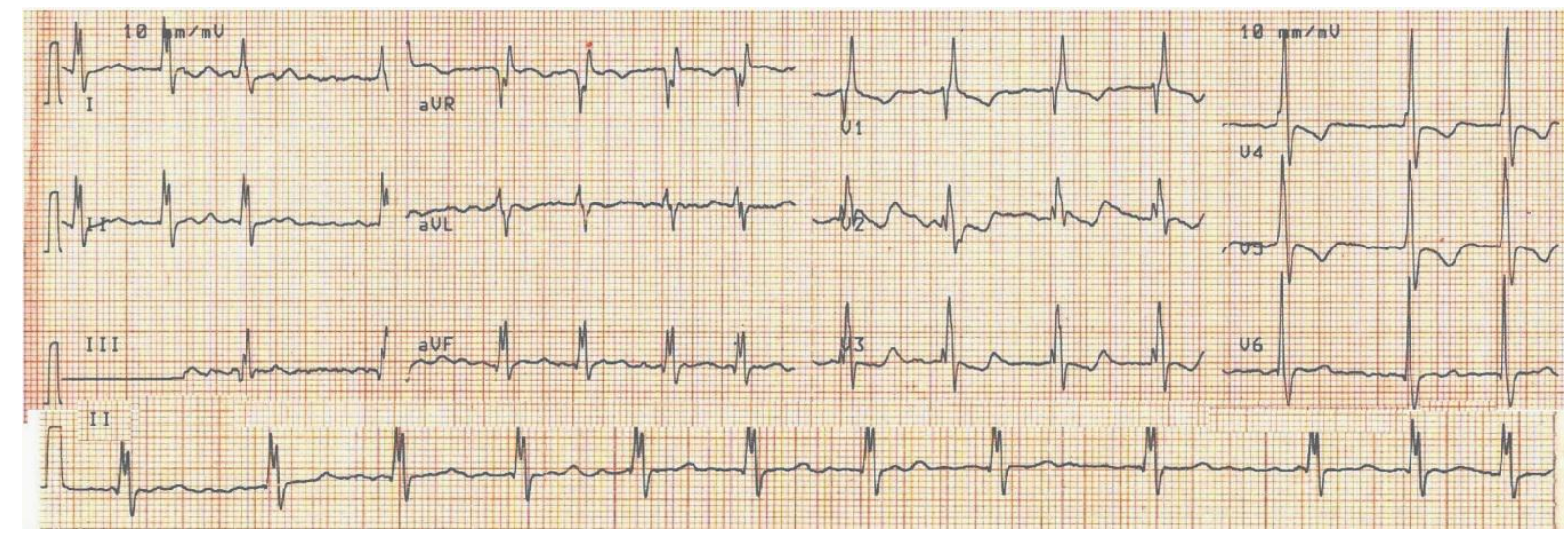

Figure 1. Electrocardiogram showing atrial fibrillation 

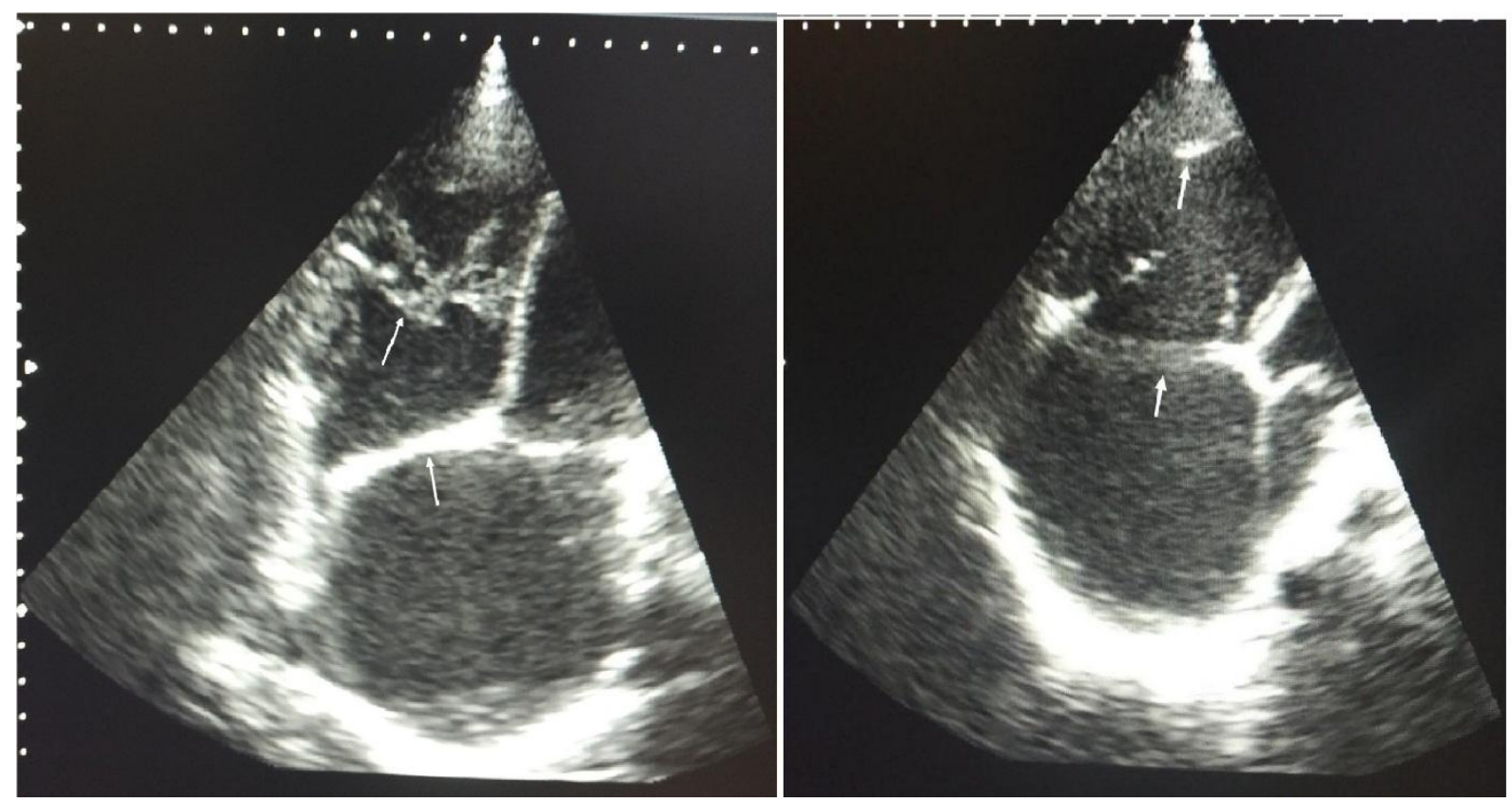

Figure 2. Transthoracic echocardiography showing accessory tissues and right cardiac dilatation

A 36-year-old woman consulted to the department of cardiology in the teaching hospital of Brazzaville for recurrent palpitations which started several months ago. The interrogation did not find a family history of congenital heart disease. At admission, the heart rythm was irregular and rate at 96 beats per minute. Blood pressure was 90/60 mmHg. Pleuropulmonary auscultation was normal. Painful hepatomegaly and hepatic jugular reflux were noted. The rest of the physical examination was boderline. The electrocardiogram recorded atrial fibrillation and a right incomplete branch block [Figure 1]. The Doppler echocardiogram revealed normal ejection fraction of left ventricle $(\mathrm{EF}=87 \%)$, dilated right cardiac cavities (right ventricle $[\mathrm{RV}]=51 \mathrm{~mm}$, right Atrium $[\mathrm{RA}]=59 \mathrm{~cm}^{2}$ ), tricuspid annular plane systolic excursion [TAPSE] $=17 \mathrm{~mm}$, presence of cardiac accessory tissues distributed as follows : one under tricuspid valve causing diastasis of tricuspid cups and significant tricuspid leak with systolic pulmonary arterial pressure at $47 \mathrm{mmHg}$; a second at the middle part of right ventricle with poorly defined outlines seeming to have a pedicled implantation base, responsible for partial obstruction of right ventricle without filling of the apex [Figure 2]. The inferior cave vein was dilated. D-dimeres were normal. No eosinophilia. Computed tomography of pulmonary arteries was normal.

Cardiac accesorry tissues causing right heart failure and atrial fibrillation was the retained diagnosis. Diuretic and anticoagulant were used as medical treatment. 


\section{Discussion}

Cardiac accessory tissues are rare, probably come from embryological vestiges. They are dominated by valvular membranes $[1,2]$. Their number is inconstant and often responsible of valvular obstruction [2]. Rythm disorders occur when cardiac fibers are deeply affected [4]. Atrial fibrillation is often related to myocardial remodeling [5] as the consequence of atrial dilatation as noted in our patient.

\section{Conclusion}

Cardiac accessory tissue is an exceptionnal cause of atrial fibrillation. Also, it is important to be attentive during echographic examination, especially in presence of valvular obstruction symptoms.

\section{References}

[1] YUAN SM, SHINFELD A, MISHALY D and al. Accessory mitral valve tissue: a case report and an updated review of literature. JCS 2008; $23: 769-72$.

[2] ARNAUD-CRAUZAT E, NOTTIN R, CHAMBRAN P et al. Tissu mitral accessoire responsable d'une gêne à l'éjection du ventricule gauche à propos de 7 cas. Arch Mal Cœur $1990 ; 83: 1579-82$.

[3] SENTILHES L, BAUER F, RESCH B et al. coeur triatrial maternel compliqué d'une fibrillation auriculaire pendant la grossesse. J Gynecol Obstet Biol Reprod 2004 ; 33 : 359.

[4] GARY T. Mechanisms of cardiac arythmias. J Arrythm 2016 ; 32 : 75-81.

[5] IWASAKI YK, NISHIDA K, KATO $\mathrm{T}$ and NATTEL $\mathrm{S}$. Atrial fibrillation pathophysiology: implications for management. Circulation 2011; 124: 2264-74. 